\title{
Major Factors that Affect Grade 10 Students' Academic Achievement in Science Education at llu Ababora General Secondary of Oromia Regional State, Ethiopia
}

\author{
Feyera Beyessa \\ Mettu College of Teacher Education, Mettu, Ethiopia
}

\begin{abstract}
The main purpose of this study was to explore the factors that affect grade10 students' academic achievement in science education at Ilu Aba Bora Zone of General Secondary Schools. To attain this objective, descriptive survey research method was employed. The subjects of the study were 360 (172 male and female 155 students, 25 science teachers, 2 laboratory technicians and 6 school principals). Stratified sampling followed by simple random sampling (lottery method) technique was employed to select the sample students, purposive sampling technique was used to select the schools and availability sampling method was employed for science subject teachers, laboratory technicians and school principals. To gather the necessary data, questionnaire, and interview, observation and document analysis were used. The gathered information was analyzed using both quantitative and qualitative methods of data analysis. The result of the study showed that students were stagnantly engaged in traditional methods of teaching science education. Of major teaching science methodologies, small group (one to five) discussion $(\mathrm{M}=4.0)$ method was the most dominant approach followed by gappedlecture and whole class discussion, which are not pedagogically supported in teaching science education of the modern time. Out of laboratory sessions, with statistically no significant difference between male and female students, they favored science education negatively and poorly involved in practicing it. $85.97 \%$ of activities in science educations of grade 9 and 10 were absolutely not done in the laboratory, which hinder students' understanding to handle science education easily. The study also revealed that, non-proficiency in English Language becomes an obstacle for students to grasp the concepts of science education. Although the professional supports of science teachers to their students were relatively fair $(\mathrm{M}=3.2)$, they have not used their maximum potential to implement science education effectively. Parental involvement, peer pressure, schools support (regular attendance, providing facilities, evaluating the effectiveness of teaching learning, giving guidance) and other stakeholders commitment to enhance students' science education were very near to the ground. Lastly, absence of laboratory chemicals, rooms, apparatuses, technicians and well organized laboratory manuals were negatively affected the effective implementation of science education and students' academic achievement as well. Thus, based on the findings of the study, recommendations were forwarded to alleviate the aforementioned problems.
\end{abstract}

Keywords: science education; teaching methodology; attitude; practice; instructional media; stakeholders and supports

\section{INTRODUCTION}

Science education is concerned with the developing of technologically literate citizens who understand how science, technology, and society influence one another and 
who are able to use this knowledge in their everyday activities. Rein \& Beach (1997) state the rationale of science education as follows; a study of science is important because it has the potential for improving the quality of life and making the world safer, empowers people, giving them greater control over their lives by providing path ways for finding answers to questions. Science education is also the field concerned with sharing science content and process, and the application of science and have transformed the world through dramatic advances in almost all fields including medicine, engineering, electronics, aeronautics etc. and in more recent times dramatic leaps in computer technology have revolutionized in particular the information and communications sector (Hallinan and Sorensen, 1987).

In this regard, strengthening their science curriculum standards China and India are two outstanding examples as they have grown to become economic and industrial powerhouses and in several ways compete effectively with developed countries (Hallinan and Sorensen, 1987). In line with this, the Malaysian Government had announced a new education policy to strengthen the education standards in science and technology to compete with advanced countries and vowed to stand in the list of developed countries in 2020 (Mahathir, 1991).These indicates that, many countries have given due attention to the effective implementation and practice of science education at their schools in general and at general secondary schools in particular.

Similarly, it is important to note that Ethiopia has placed education at the center of its strategies for development and decentralization, with strong polices promoting quality of educational provision (TGE, 1994). Definitely, the Ethiopian Government has also given emphasis on fields of science, mathematics and technology. Therefore, Ethiopia has to gear itself to provide the required training in scientific skills to meet the growing challenges of the world. Hence, the standards for science education provide expectations for the development of understanding for students through the entire course of general secondary school. This is because of science education is the fundamental one to the road of rapidly changing the world.

\section{Statement of the Problem}

To achieve the expected learning outcomes in science education, the Ethiopian government has now shifted its attention to improve quality of education with General Education Quality Improvement Package programs that have been positively influence students' achievement (Ministry of Education/MOE, 2004). In the same way, the intention of Ethiopian Government is attempting to increase the number of graduates especially in the fields of science, technology and innovation to become knowledgeable workers to sustain the nation and to achieve the title of middle developed nation.

However, there are challenges that recent education reforms proposed changes in the school curriculum, mode of delivery, teacher education programs and the assessment techniques (MOE, 2002). The Ministry of Education (MOE, 2004) also reported that the quality of teaching learning process in Ethiopian schools is very low. Similarly, in the national learning assessment of grade 10 and 12 students, the academic achievement of the students measured by the mean score of the five subjects namely English, Mathematics, Biology, Chemistry and Physics was found to be less than the minimum requirement (50\%) achievement level set by the Education and training policy of Ethiopia. That is the national mean score (the average of what the students scored in five subjects) was only $35 \%$ for grade 10 and $47.8 \%$ for grade 12 (Zewdu, 2010).

Consequently, in 2009/2010 G.C. or 2002E.C the Ethiopian general secondary school leaving examination result also shows that $24.76 \%$ grade 10 students were promoted to 
preparatory schools and in particular to Ilu Abba Bora zone, $12.12 \%$ of grade 10 students were promoted to preparatory schools (OEB, 2012).

Table 1. Grade 10 students' letter grade achievements in 2013 G.C by stream.

\begin{tabular}{|c|c|c|c|c|c|c|c|}
\hline \multirow[b]{2}{*}{ No } & \multirow[b]{2}{*}{ Streams } & \multirow{2}{*}{$\begin{array}{l}\text { No of students } \\
\text { who sat for } \\
\text { leaving } \\
\text { examination }\end{array}$} & A & B & $\mathrm{C}$ & $\mathrm{D}$ & $\mathrm{F}$ \\
\hline & & & $\begin{array}{l}\text { in } \\
\%\end{array}$ & $\begin{array}{l}\text { in } \\
\%\end{array}$ & $\begin{array}{l}\text { in } \\
\%\end{array}$ & $\begin{array}{l}\text { in } \\
\%\end{array}$ & $\begin{array}{l}\text { in } \\
\%\end{array}$ \\
\hline 1 & Language & 8124 & 2.45 & 10.01 & 50.21 & 33.24 & 4.05 \\
\hline 2 & Natural science & 8124 & 1.47 & 6.95 & 55.95 & 29.71 & 5.92 \\
\hline 3 & Social science & 8124 & 4.25 & 14.2 & 41.23 & 29.76 & 10.58 \\
\hline
\end{tabular}

Source: Zone Education Office Document of 2013 G.C.

From Table 1, it is observed that the students' academic achievement of natural science / science education are $1.47 \%$ and $6.95 \%$ of the students who sat for Ethiopian general secondary school leaving examination scored letter grade achievements A and B respectively. Indeed, this directly implies that the students' academic achievement in natural science is relatively the least of the three streams stated above. Hence, this study assesses the major factors that affect students' academic achievement in science education at Ilu Abba Bora zone of general secondary schools.

\section{Basic Questions of the Study} questions.

Based on the stated problem, the study will attempt to provide answers to the following

1. How do students engaged in teaching methodology of science education?

2. What are the attitudes of students toward the science education?

3. How do students involved in practicing science education?

4. Is there a significant difference in between male and female students in their attitude towards science education and practicing it?

5. How do students get supports in science education?

6. What are the contributions of concerned stakeholders to improve students' achievement in science education?

\section{Scope of the Study}

The study was delimited to the Ilu Abba Bora general secondary schools, of the Oromia Region for the fact that the problem of this study is the serious issue of the Zone. The study was focused on grade 10 students excluding grade 9 students. This is because they have been stayed in the school for two years and have been preparing themselves for the General Ethiopian Schools Leaving Certificate Examination. Out of many aspects to be considered in assessing factors related to students achievement; teaching methodology of science education, students' attitude and practice and support given to students and the role of concerned stakeholders in the implementation of science education are the focus of this study. 


\section{Significances of the Study}

To achieve the main objectives of science education in Oromia region / Ethiopia, Ilu A/Boora general secondary schools should look for all factors that are related to the students' academic achievement in science subjects. Accordingly, the study may be significant in the following regards:

$>$ This study would help Ministry of Education/ Oromia Education Office to identify ways to improve students' achievement in science and formulating policies pertaining to resource allocation in the improvement of science education;

$>$ It gives general direction for Ilu Abba Bora Zone of education office to determine ways to enhance students' achievement and helps them to take measurable actions for further improvement of the teaching learning process;

$>$ It helps the science teachers to improve their teaching methods, professional supports and assessments techniques;

$>$ It helps students to be competent in a complex scientific and technological world.

$>$ It enables school principals to improve the effectiveness of teaching learning process in the school by providing more than expected supports;

$>$ It throws more light to science teachers and laboratory technicians to evaluate their professional support to improve the students' academic achievement;

$>$ It helps parents to give more support to their students psychologically and financially;

$>$ It helps concerned stakeholders to be involved very much in improving students' academic achievement in science education.

\section{Review of Related Literature}

Science teaching involves teaching students to use their knowledge, beliefs, and Meta cognitive and affective thought processes to generate new, fruitful, and transferable conceptions that have personal and every day meaning and significance (Wittrock, 1994). As a result, effective science teaching to leave students with the ability, and the motivation, to solve problems scientifically and to carry out scientific investigation. Hence, effective instructional strategies involve knowledge of multiple methods or activity sequences that lead to successful student learning and a specific concept or process skill (AAPT, 2009).

\section{Students' Attitude towards Science Education and their practices}

Students' attitude and their academic achievement in science education have direct relation. Students with positive attitude towards science education have high achievement and the affective practices of students in and out of the classroom are strongly related to their academic achievement (George and Kaplan, 1998). Students are effectively successful through practicing the subject matters. Similarly Farounbi (1998) argued that students tend to understand and recall what they see more than what they hear as a result of using laboratories in the teaching and learning of science students so as to get better achievement. While practicing science education, scholars indicate that the most important factor with positive effect on students' performance is student's competence in English Language, and if the students have strong communication skills and have strong grip on English language, it increases the practices and the performance of the students (Harb and El-Shaarawi, 2006) in their teaching learning process. 


\section{Supports to Students (direct)}

Teachers' professional support constitutes uncountable actions and activities that improve student outcomes (Staver, 2007). In the same way, parents can also play a vital role in their children's education. Regarding this, Henderson and Mapp (2002:7) explains that "students with involved parents, no matter what their income or background, were more likely to earn higher grades and test scores and enroll in higher-level programs; be promoted, pass their classes, attend school regularly with better social skills and improved behavior so as to go on to post general secondary education". Moreover, peer supports influence as a powerful indicator of students' academic success. This means, peers can be a source of motivation by influencing an individual's educational achievements and a source of information regarding the benefits of school success (Natriello and McDill, 1986).

\section{Supports from Other Concerned Stakeholders to Students (indirect)}

Ornstein and Hunkins (1998) considered the school principals as key guarantor of successful implementation of the school curriculum so as to improve students' academic achievement. According to them, school principals are those who are knowledgeable and committed to the curriculum and they also view their roles in providing encouragements on one end of the continuum and serving as curriculum leaders on the other end. The school personnel, members of the families and communities provide help and support to students for the quality of their academic performance with critical academic for the accomplishment of performance goals of students at school (Goddard, 2003). Concerning district educational structural organization, Robert \& Sampson (2011) found that the member of Kebele Education and Management Board (KETMB) and Parent Teachers Associations (PTAs) will be educated and their impact on school is positive and they have to put essential educational foundation for students' learning and engaging with healthy teaching learning process. The students who are actively engage in the learning process are observed to have a positive correlation with the achievement. Likewise, providing supervisory service through different strategies of school based instructional supervision such as induction, mentoring, clinical supervision, collegial supervision and informal supervision have great positive impact in strengthening teachers instructional skills (OREB, 2007) so as to improve the students' academic performance.

In the decentralized education structure of Ethiopia, Woreda Education Offices (WEOs) has been given mandated to give vital support for the implementation of teachers' programs. Thus, they have roles and responsibilities (MOE, 2004) to: plan, organize, coordinate, supervise and support and ensure their effective implementation of science education in the local context, so as to enhance students' performance. In most case studies and reports in the literature, schools and Higher Education Institutions (HEIs) that have meaningful partnerships are located in the same geographical area (Villegas-Reimers, 2003) to transform science education skills. In addition to this, the contribution of Non Governmental Organizations (NGOs) to the improvement of science education should not be under estimated [Strengthening Mathematics and Science Education in Ethiopia (SMASEE, 2012)]. It is obvious that schools have to provide necessary materials (books, classrooms, laboratory materials, guidance on teaching learning of science education and others) for students so that students have to get access in achieving their science subjects effectively (Norhidayah Ali, et. al., 2009). Generally,some educational experts argue that students' poor attendance made by schools is not only hinders academic achievement but also promotes a poorly educated society and thus leads to many negative social issues. That is, poor attendance, proceeds to low achievement, 
increases the dropout rate, and amplifies a host of social problems (Collins, 1982 cited in Raychaudhuri, et al, 2010).

\section{RESEARCH METHOD}

In this study the research method that was used was the descriptive survey research method for this method is regarded as appropriate for the study of attitudes, opinions, preferences, demographics, practices and procedures (Gay and Airasia, 2000).

\section{Sources of Data}

Primary data sources include students, science teachers and school principal. The secondary data sources were, teachers' attendance during laboratory practice, make up and tutorial sessions, student records and other documents with respect to activities at school.

\section{Samples and Sampling Techniques}

Out of 28 general secondary schools of Ilu Aba Bora zone 6 (21.4\%) schools were selected using purposive sampling technique for the fact that they are the least achievers of all schools. Out of 1121 students, first stratified sampling was used to divide $327(29.2 \%)$ students in to two groups and then followed by simple random sampling (lottery method) to select (male $30.5 \%$ ) and (female $27.8 \%$ ) for they are in the same grade level. Availability sampling was used to select 6 school principals, 2 laboratory technicians and 25 science teachers for they are the direct implementers of the science education curriculum. Thus, the subjects of the study were 360 .

\section{Data Gathering Instruments}

Questionnaires of open-ended (12 items) and close-ended (69 items) were used based on the Likert-type opinion of five scales having 5 degree of agreements. In addition, 30 set of interviews were used for school principals and science teachers respectively. Furthermore, 11 set of structured observation was used to investigate activities relevant to answering the research questions. Finally, document analysis was carried out on students' science text books, teachers' supports, school documents and activities done in the laboratory.

\section{Procedure and Data Analysis Strategy}

After developing the data collecting instruments, the researcher have given to two science teachers so as to improve the validity of the questionnaire and then a pilot test of instruments was made in both 46 students respondents to make the instruments dependable and to be finally used in the actual study with the overall Cronbach's alpha 0.91. This shows that the instruments were highly reliable to collect relevant information.

The quantitative data obtained from close-questionnaire were analyzed using both descriptive and inferential statistics. Percentage, mean and standard deviation were used to describe categorical data regarding the contribution of parents, subject teachers, pears, and school. Similarly, t-teat was employed to see whether there were mean difference between male and female students' attitudes towards science education, and their actual practices in science education at 0.05 confidence levels. Finally, data gathered through interviews, document analysis, observation techniques were analyzed qualitatively. 


\section{Data Analysis and Interpretation}

This part of the paper deals with the presentation and analysis of data collected from the respondents to address the basic research questions. The close-ended questionnaires of Likert scale having five degree of agreements such as; Strongly Agree $=5$; Agree $=4$; Undecided $=$ 3; Disagree $=2$ and Strongly Disagree $=1$ were used for students 'attitudes. Whereas, Very High $=5$, High $=4$, Medium $=3$, Low $=2$ and Very Low $=1$ questionnaires were used to gather data regarding students' practices, and support given to them. Thus, it is obvious that the average mean five scales is 3.0. Note that, Mean (M) and standard deviation (St. Dev.).

Chart 1. Students Engagement in Teachers Methods of Teaching Science Education.

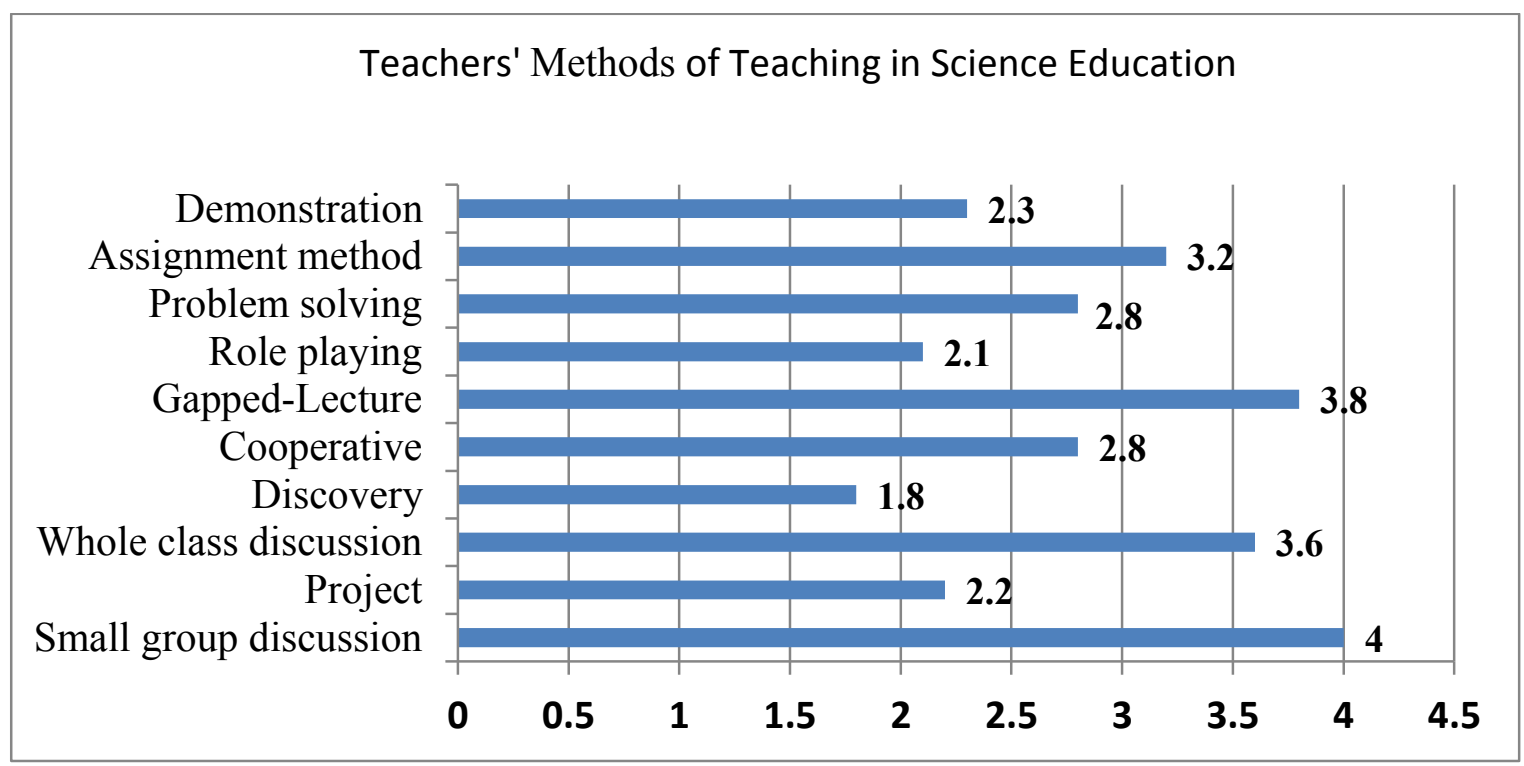

As can be seen from Chart 1, science subject teachers have used assignment $(\mathrm{M}=3.2)$, gapped lecture $(\mathrm{M}=3.8)$, whole class discussion $(\mathrm{M}=3.6)$ and small group discussion $(\mathrm{M}=$ 4.0) methods above the expected mean value. Whereas, in the same table, teachers have used demonstration $(\mathrm{M}=2.3)$, problem solving method $(\mathrm{M}=2.8)$, cooperative (one-in-five) $(\mathrm{M}=$ $2.8)$, role playing $(\mathrm{M}=2.1)$, discovery $(\mathrm{M}=1.8)$ and project (2.2) methods below the expected students' engagement in effective teaching strategy. However, effective and multiple approaches of instructional strategies involve knowledge of multiple methods or activity sequences that lead to successful student learning and a specific concept or process skill (AAPT, 2009).

Hence, the researcher may sum up that science teaching of the past time, with its pattern of monotonous lecturing and discussion will not help students to build a deep and coherent understanding. For this fact, it is possible to say that less students' engagement in effective teaching methodology of science education can be considered as the one factor that affect students' academic achievement. 
Table 2. Students' Attitude towards Science Education.

\begin{tabular}{|c|c|c|c|c|c|c|}
\hline No & Items & Types of sex & Mean & St. Dev. & t-val. & P-val. \\
\hline 1 & I need to do well science education & $\begin{array}{c}\text { Male } \\
\text { Female }\end{array}$ & $\begin{array}{l}2.66 \\
2.87\end{array}$ & $\begin{array}{l}1.29 \\
1.26\end{array}$ & 1.46 & 0.14 \\
\hline 2 & Science education is my favorite subjects & $\begin{array}{c}\text { Male } \\
\text { Female }\end{array}$ & $\begin{array}{l}2.93 \\
3.10\end{array}$ & $\begin{array}{l}1.15 \\
1.31\end{array}$ & 1.31 & 0.19 \\
\hline 3 & $\begin{array}{l}\text { I believe science education has contributed to my } \\
\text { knowledge }\end{array}$ & $\begin{array}{l}\text { Male } \\
\text { Female }\end{array}$ & $\begin{array}{l}2.75 \\
2.91\end{array}$ & $\begin{array}{l}1.29 \\
1.30\end{array}$ & 1.15 & 0.24 \\
\hline 4 & I feel happy in learning science & $\begin{array}{c}\text { Male } \\
\text { Female }\end{array}$ & $\begin{array}{l}3.07 \\
2.75\end{array}$ & $\begin{array}{l}1.32 \\
1.29\end{array}$ & $2.21 *$ & 0.02 \\
\hline 5 & I hope science education helps me to create job & $\begin{array}{c}\text { Male } \\
\text { Female }\end{array}$ & $\begin{array}{l}3.06 \\
3.10\end{array}$ & $\begin{array}{l}1.32 \\
1.31\end{array}$ & .26 & 0.78 \\
\hline 6 & $\begin{array}{l}\text { I feel happy while solving } \\
\text { problems related to science education }\end{array}$ & $\begin{array}{c}\text { Male } \\
\text { Female }\end{array}$ & $\begin{array}{l}3.01 \\
3.09\end{array}$ & $\begin{array}{l}1.25 \\
1.25\end{array}$ & .56 & 0.57 \\
\hline 7 & I wait for science period eagerly. & $\begin{array}{c}\text { Male } \\
\text { Female }\end{array}$ & $\begin{array}{l}3.13 \\
3.01\end{array}$ & $\begin{array}{l}1.25 \\
1.21\end{array}$ & .87 & .38 \\
\hline 8 & $\begin{array}{l}\text { I hope that science education help me in my } \\
\text { future activities }\end{array}$ & $\begin{array}{c}\text { Male } \\
\text { Female }\end{array}$ & $\begin{array}{l}2.81 \\
2.69\end{array}$ & $\begin{array}{l}1.28 \\
1.23\end{array}$ & .83 & .40 \\
\hline 9 & I am interested in activities of science education & $\begin{array}{c}\text { Male } \\
\text { Female }\end{array}$ & $\begin{array}{l}3.06 \\
2.98\end{array}$ & $\begin{array}{l}1.16 \\
1.18\end{array}$ & 63 & .52 \\
\hline 10 & I I attend science education regularly & $\begin{array}{c}\text { Male } \\
\text { Female }\end{array}$ & $\begin{array}{l}2.89 \\
2.97\end{array}$ & $\begin{array}{l}1.08 \\
1.13\end{array}$ & .64 & .52 \\
\hline \multicolumn{3}{|c|}{ The overall mean score } & 2.94 & \multicolumn{3}{|c|}{$*=\mathrm{P}<0.05$} \\
\hline
\end{tabular}

The analysis $(\mathrm{t}=2.21, \mathrm{df}=326$ and $\mathrm{P}<0.05)$ of Table 2 shows that there was statistically difference between male and female students attitudes while learning science education. That is female students fell happy to learn science education than male students. Whereas, the analysis $(\mathrm{t}<2.21$, $\mathrm{df}=326$ and $\mathrm{P}>0.05)$ indicates that there were statistically no difference between male and female students attitudes toward science education. Generally, the overall mean score $(M=2.94)$ shows that both male and female students have less interest in attending, believing, having good interest, doing, solving some activities of science education. Thus, it can be understood that having the negative attitude toward science education is another influential factor to the low academic achievement of students. 
Table 3. Students' Practice out of Laboratory Session in Science Education.

\begin{tabular}{|c|c|c|c|c|c|c|}
\hline No & Items & Types of sex & Mean & St. Dev & t-Val. & P-Val \\
\hline 1 & I do home works & $\begin{array}{c}\text { Male } \\
\text { Female }\end{array}$ & $\begin{array}{l}2.40 \\
2.49\end{array}$ & $\begin{array}{l}.87 \\
.89\end{array}$ & $.85^{*}$ & .39 \\
\hline 2 & I do class work at a given time & $\begin{array}{c}\text { Male } \\
\text { Female }\end{array}$ & $\begin{array}{l}2.46 \\
2.50\end{array}$ & $\begin{array}{l}1.01 \\
.90\end{array}$ & $.41 *$ & 67 \\
\hline 3 & I do assignments & $\begin{array}{c}\text { Male } \\
\text { Female }\end{array}$ & $\begin{array}{l}2.98 \\
3.01\end{array}$ & $\begin{array}{l}1.30 \\
1.26\end{array}$ & $.17 *$ & .86 \\
\hline 4 & I do exercises related to science education & $\begin{array}{c}\text { Male } \\
\text { Female }\end{array}$ & $\begin{array}{l}2.61 \\
2.68\end{array}$ & $\begin{array}{l}.86 \\
.88\end{array}$ & $.75^{*}$ & .44 \\
\hline 5 & I usually solve problems of science education & $\begin{array}{c}\text { Male } \\
\text { Female }\end{array}$ & $\begin{array}{l}2.46 \\
2.60\end{array}$ & $\begin{array}{l}.90 \\
.84\end{array}$ & $1.46^{*}$ & .14 \\
\hline 6 & I participate on group work & $\begin{array}{c}\text { Male } \\
\text { Female }\end{array}$ & $\begin{array}{l}3.16 \\
3.07\end{array}$ & $\begin{array}{l}1.21 \\
1.23\end{array}$ & $.67 *$ & .50 \\
\hline 7 & I am involved in any science activities & $\begin{array}{c}\text { Male } \\
\text { Female }\end{array}$ & $\begin{array}{l}2.72 \\
2.72\end{array}$ & $\begin{array}{l}.88 \\
.93\end{array}$ & $.04 *$ & .96 \\
\hline 8 & I take time to read/study science education & $\begin{array}{c}\text { Male } \\
\text { Female }\end{array}$ & $\begin{array}{l}2.73 \\
2.65\end{array}$ & $\begin{array}{l}1.02 \\
1.05\end{array}$ & $.64 *$ & .51 \\
\hline 9 & $\begin{array}{l}\text { I relate activities of science education to the real } \\
\text { world }\end{array}$ & $\begin{array}{c}\text { Male } \\
\text { Female }\end{array}$ & $\begin{array}{l}2.87 \\
2.65\end{array}$ & $\begin{array}{l}2.48 \\
1.04\end{array}$ & $.99 *$ & .32 \\
\hline 10 & I use other science materials/books & $\begin{array}{c}\text { Male } \\
\text { Female }\end{array}$ & $\begin{array}{l}2.69 \\
2.73\end{array}$ & $\begin{array}{l}1.07 \\
.93\end{array}$ & $.39 *$ & .69 \\
\hline \multicolumn{3}{|c|}{ The overall mean score } & 2.70 & \multicolumn{3}{|c|}{$*=\mathbf{P}>0.05$} \\
\hline
\end{tabular}

The analysis $(\mathrm{t}<=1.46$, $\mathrm{df}=326$, and $\mathrm{P}>0.05)$ of Table 3 shows that there were statistically no difference between male and female students in practicing science education. The overall mean score $(\mathrm{M}=2.70)$ indicates both groups of students have practiced below moderate practice in doing home works, assignments, class works, and activities of science education.

Students are demoralized and have been focused on extra business [eg. harvesting coffee (which makes students usually out of the schools for several days and not to practice science education) and additional business duty] for 
the fact that there are many university graduates, who are jobless/ working irrelevant jobs (interviewed on 07/08/05 E.C).

From the analyses, one can say that students' less effort in practicing science education is another leading factor to enhance students' academic achievement in science education.

Chart 2. Students' Practices of Laboratory Activities.

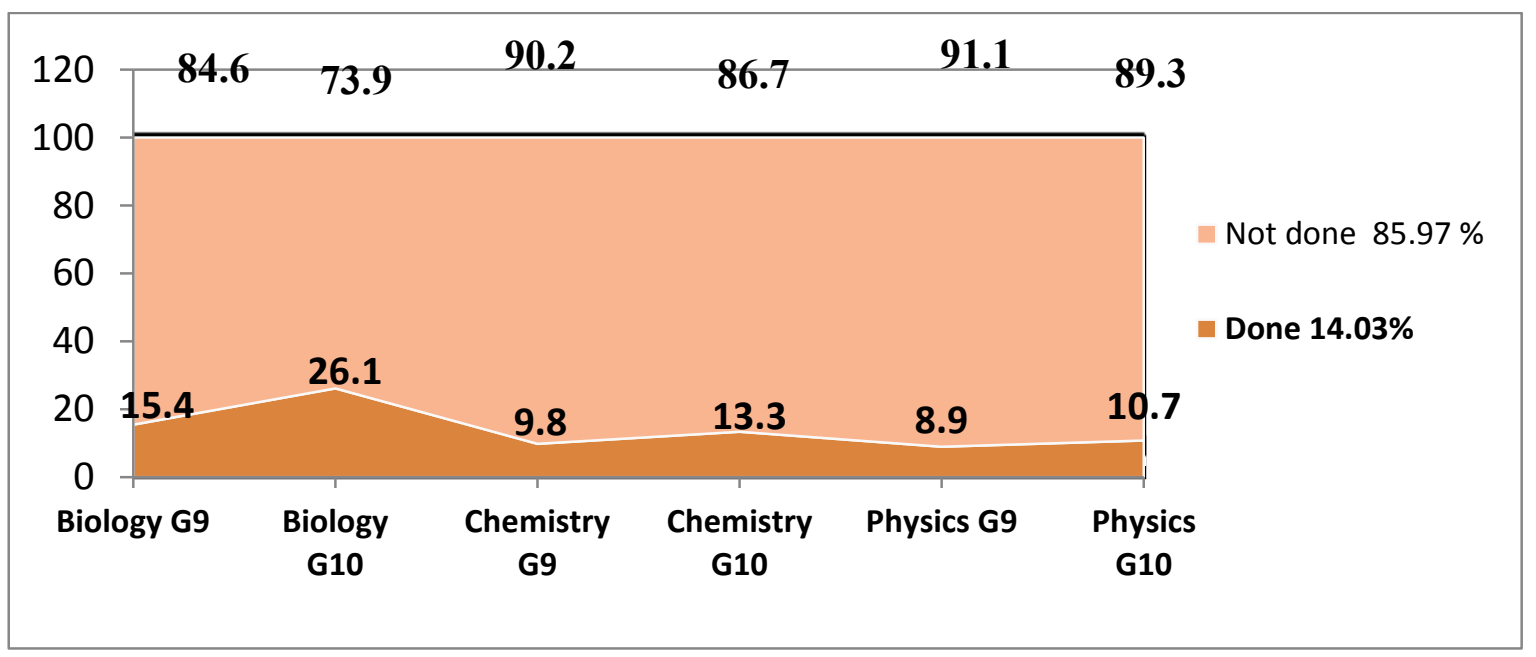

Chart 2 shows the analysis of laboratory practice in science education in grade nine and ten. Out of total activities in science curriculum of grade 9 and 10, only $14.03 \%$ laboratory activities were done, which have contributed insignificant input to the students. On the other hand, $85.97 \%$ of laboratory activities were not done in science education of general secondary schools under which the study was conducted. This implies that very low activities of students' laboratory practices have been considered as major factors which affect the students' academic achievement in science education.

From the researchers personal observation there were some hindering factors to practice laboratory experiments, which makes negative impact on students' academic achievement in science education:

$>$ The absence of laboratory technician for Biology, Chemistry and Physics in the school, who can carefully practice in the laboratory.

$>$ To practice laboratory experiments, there are no well prepared laboratory manuals.

$>$ Chemicals, apparatus and laboratory room haven given less function for the fact that the chemicals on the laboratory are highly expired and outdated, and dangerous for the students as well as for the laboratory technicians.

$>$ The laboratory room does not match with the number of students.

$>$ Some schools do not have totally laboratory rooms, materials and technicians.

These hindering factors show that students do not get satisfactory laboratory practices. As a result of these analyses, definitely, one can easily recognize that the very low laboratory practices at general secondary schools of Ilu Aba Bora zone was the most dominant negative impact on students' academic achievement in science education. 
Table 4. Students and Teachers Views on Students' Practice Using Instructional Media.

\begin{tabular}{|c|c|}
\hline Students' mean Score & 2.98 \\
\hline Teachers' mean score & 2.92 \\
\hline
\end{tabular}

As can be seen from Table 4, the mean score of students' response $(\mathrm{M}=2.98)$ and teachers' response $(\mathrm{M}=2.92)$ show that students were at low position in using English as medium if instruction in science education were below the expected practices. Non-proficiency in English Language becomes an obstacle for students to grasp the concepts of science education in their study. The deficiency of students is not only in the level of their English Language skills, but in general mastery science subject knowledge. Regarding this, some teachers were interviewed and they pointed out that:

Students feel uncomfortable in understanding the subject matter, which is not in their own language. Further, the teachers were found unsatisfied about student's performance at the general secondary level as the medium of instruction is English Language and no one can deny with the importance of medium of instruction in the achievement level of students but it adversely influence the achievement level when the medium of instruction changes from mother tongue to English Language at general secondary stage in Ethiopia. It becomes a dilemma for students because up to primary level students have been taught in English Language as a text which is not sufficient for students to handle the change of medium of instruction from mother tongue to English Language. (interviewed on 08/08/05 E.C).

Chart 3. Students' Direct Supports in their Science Education.

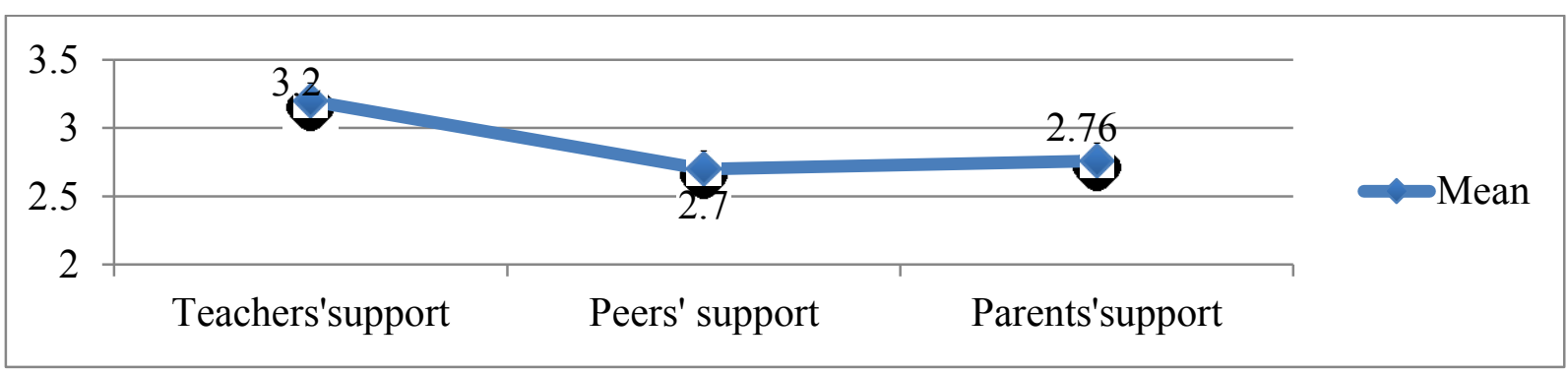

The mean score, $\mathrm{M}=3.2$ in Chart 3 shows that teachers professional support to their students in science education is more than average contributions. Although teachers have contributed more than average support, they haven't used their maximum efforts to support their students in science education for the following interview reasons.

The interview result also shows that students' low interest of students in attending makeup and tutorial class, behavior, practice... are the main reason for the low professional support of teachers. And even during make 


\begin{abstract}
up and tutorial classes, out of fifty students only up to five or six students were attended, which leads to reduce the moral of teachers to give sufficient professional support (interviewed on 07/08/05 E.C).
\end{abstract}

The parents' support with mean score $(M=2.7)$ to their students is minimum. Students at general secondary schools are beyond the control of their parents. Majority of the parents were tried to send their students with some materials and finances to the school with less efforts to communicate with the schools/subject teachers on the issue of students' academic achievement in science education (interviewed on 07/08/05 E.C). Finally, $\mathrm{M}=2.76$ realizes that students have very weak peer supports and coordination in doing all activities of science education. For this reason, it is possible to generalize that such kind of minimum parental involvement in supporting their students and poor coordination/network among students in doing science education were the critical impact to the low achievement of students' academic achievement in science education at general secondary schools of Ilu Abba Bora Zone.

Chart 4. Other Stakeholders Supports to Students' Academic Achievement in Science Education.

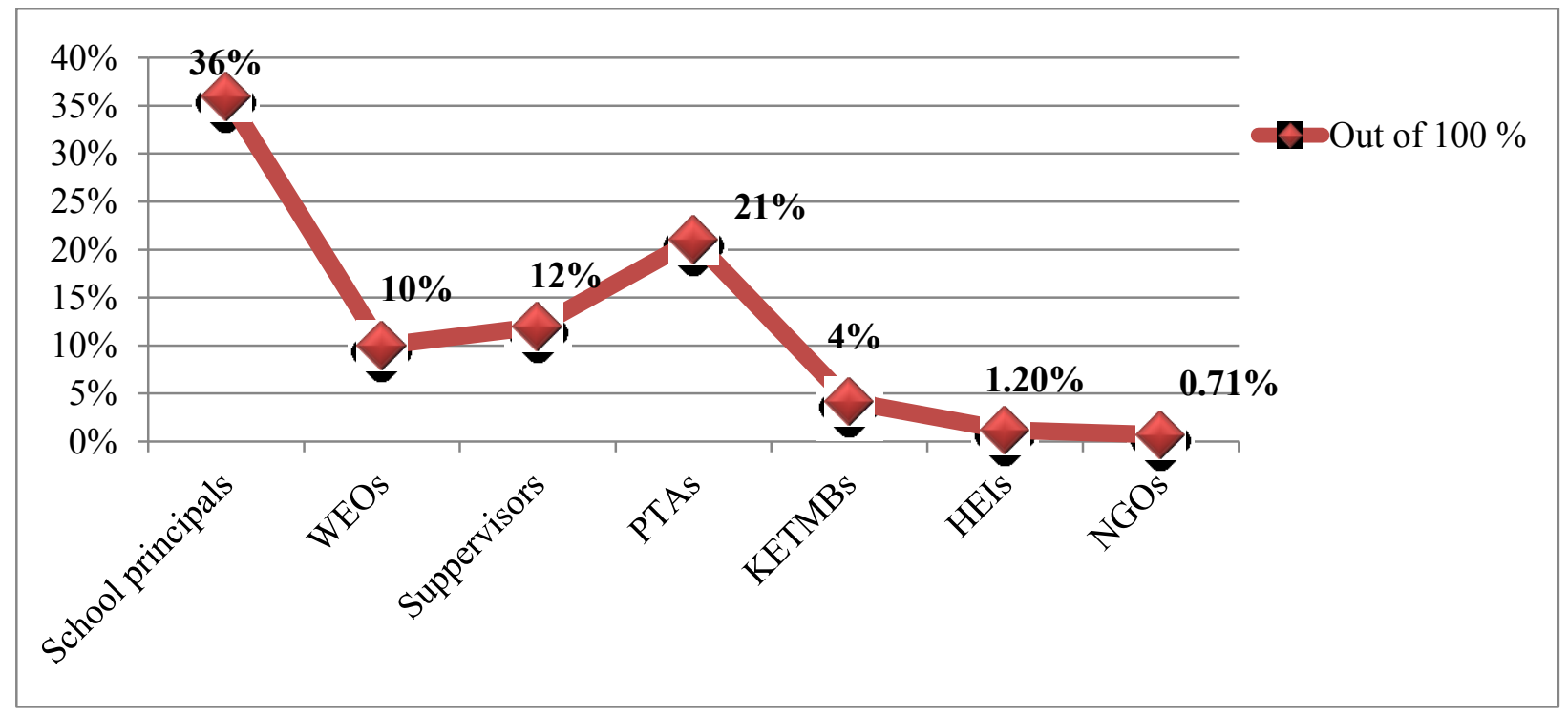

Ornstein and Hunkins (1998) examines that the school principals as key guarantor of successful implementation of the school curriculum so as to improve students' academic achievement. The supports of school principals $(36 \%)$, is not in line with their duties and responsibilities stated in the policy. Similarly, WEOs (10\%), supervisors (12\%), PTAs $(21 \%)$ and KETMBs (4\%), to students in teaching learning of science education are ineffective. In the same way, WEOs and supervisors have given emphasis only on collecting data regarding students' enrolment, dropout, other information and controlling rather they have given very less emphasis on technical and professional advice in enhancing the implementation of science education. Some schools like Bure and Burrusa general secondary schools haven't any supervisors. Regarding the PTAs and KETMBs contribution, they focused on the physical aspects of the school construction (laboratory, additional rooms) rather their support in increasing students' science academic achievement minimum. Even, they haven't well established school plan, vision and awareness about the technical and academic issues for the implementation of science education. 
Consequently, the contributions of HEIs (1.2\%) and NGOs (0.71) in supporting general secondary schools in science education were uncountable. Yet, schools and universities that have meaningful partnerships are located in the same geographical area (Villegas-Reimers, 2003) to transform effective and new technology based science education skills. The support of Education Strategic Objective (BESO), the United Nations Children's Fund (UNICEF), World Vision, in general and Japanese International Cooperation Agency (JICA) in particular to support general secondary schools in aspects of professional, technical, material, financial and resources cannot be understated to improve science education skills in the schools. Hence, one can generalize that there is a great implementation gap among key stakeholders to support science education that leads to the very less students' academic in science education in general secondary schools of Ilu Aba Bora Zone. In line with this, the support of schools to the students' academic achievement science teachers' interview result realized that:

Schools have no clear stand on students' attendance and they were devoted to reduce dropout. For instance, students who stayed out of the school for two three months are searched and allowed to attend their regular classes and encouraged to be promoted to the next class with very poor academic performance. The schools force teachers to collect such students through all kebeles/district areas so as reduce dropout. For these fact, students' absenteeism from regular class, makeup, tutorial class are beyond the control of teachers, this leads students' care lessens to attend science education. We afraid to talk/teach about science education in front of such students, and hence science education is considered as insignificant subjects for them (interviewed on 11/08/2005).

\section{CONCLUSIONS AND RECOMMENDATIONS}

Based on the above findings, the following conclusions and recommendations were drawn:

1. It has been found that teaching science with the past approach and traditional teaching methods can affect students' academic achievement in science education. Thus, Ethiopia/ Oromia science education project, which enhances the skills of science teachers, has to be established so as to transform science education for learners to become scientists. Science teachers have to engage their students by taking some measure of control over critical aspects of instruction, including various grouping styles with effective teaching methodology.

2. With statistically no significant difference between both male and female students, they have shown relatively below the normal attitudes towards science education. Therefore, a great awareness on the importance of science education has to be given to students by role model professionals, educational structural organizations and science teachers.

3. Regarding students' practice in science education out of laboratory session, with statistically no significant difference between male and female students and they have showed fewer efforts to practice science education. Thus, general secondary schools, teachers and other concerned bodies should be committed to build students' confidence in their ability to do well and better. They should check the practice of students' science education for students in general to female students in particular so as to enhance the low performance of students in the subjects under investigation. To be knowledgeable person about the important concepts and theories of 
the three major branches of science education in the 21 st century is needed; students have to be comfortable and competent in a complex scientific and technological world. Thus, students should take an active role by taking responsibility for their own learning, developing goals for themselves, and asking for help when needed.

4. It can be said that the very low laboratory practices at general secondary schools of Ilu Aba Bora Zone have made leading negative impact on students' academic achievement in science education. Therefore, Ministry of Education and Oromia Education Bureau have to fulfill well-trained laboratory technicians, chemicals, apparatuses, and well designed laboratory manuals. They should also give a great attention to eliminate the outdated and expired chemical from general secondary schools. Schools have to take care for the exiting laboratory chemicals, apparatuses, and tried to arrange for effective implementation of laboratory activities as well.

5. Since medium of instruction at primary schools (grade 1-8) is mother tongue and at general secondary schools is English Language, it can be concluded that non-proficiency in English language becomes an obstacle for students to grasp the concepts of science education. Hence, educational structural organizations, policy makers and curriculum designers have to put strong foundations and special attention to English Language at primary level so that students can effectively use English Language in their science education at general secondary school.

6. Al though teachers have contributed more than average support, they haven't used their maximum professional efforts to support their students in science education. Science education teachers have to be fully committed to provide effective professional support to their students in science education by working together as a professional colleagues.

7. The study revealed that less parental involvement and peer support were the critical impact to the low achievement of students' academic achievement in science education. Therefore, parents should get effective awareness on the importance and benefit of science education by school principal and other concerned district educational structural organizations so that they can support their daughters and sons effectively. Teachers and school administration should make the spirit of peer educational cooperation among students so that students may work with strong network to improve their academic achievement science achievement.

8. The study showed that school principals' contribution were relatively not as expected as first line manager. Therefore, school principals have to focus on effective teaching learning and create their own vision to enhance science teaching in line with the policy by including teachers, parents, administrators, and school board members and they have to work in line with their duties and responsibilities given to them by the policy.

9. From the results of the study, PTA and KERMB, ZEOs, WEOs and supervisors have given less emphasis on technical, professional and collaborative support in enhancing the implementation of science education. Thus, they have to create their own science education vision and support in line with their duties and responsibilities to produce talented students, who will be prepared well for the 21 st century engineers and scientists.

10. The result of the study shows that HEIs and NGOs contribution to science education is almost none. Therefore, local or international NGOs should focus in improving science education in general secondary schools like the contribution of Japanese International Cooperation Agency (JICA) for Strengthening Mathematics and Science Education in Ethiopia 
(SEMASEE) at grade 7 and 8. Ilu Aba Bora Zone education office has also to play greater role in strengthening the effective and sustainable partnerships between HEIs and general secondary schools so as to strengthen students' academic achievement in science education.

11. Since, Ethiopia has been moved to the industrial zone, the country needs well trained man power in the fields of science education and the central missions of all educational institutions / schools are to form and produce good citizens, academically talented and future scientists. Therefore, in order to have students with high science achievement, schools should give special attention to the implement effective science teaching, new science strategic plan, regular students' school attendance and make strong collaboration with various key stakeholders.

\section{References}

[1] AAPT (2009). The Role, Education, Qualification, \& Professional Development of Secondary School physics Teachers. Retrieved on December 25, 2011, from http://WWW.aapt.org.

[2] Farounbi M. (1998). Resource concentration, utilization and management correlates of students'. Learning outcomes: a study in school quality in Oyo State. University of Ibadan, Ibadan.

[3] Gay L. R., Airasia P. (2000). Educational Research: Competences for Analysis and Application. ( $6^{\text {th }}$ ed.).New Jersy: Prentice-Hall, Inc.

[4] George R., Kaplan M. D. (1998). A structural model of parent and Teacher influences on students' attitudes of eight grades. Evidence from NELS: 88 Science, 82(1); 93-109.

[5] Goddard R. D. (2003). Relational networks, social trust, and norms: A social capital perspective on students' chances of academic success. Educational Evaluations \& Policy Analysis, 25; 59-74.

[6] Hallinan Maureen T.., Aage B. Sorensen. (1987). "Ability Grouping and Sex Differences in Mathematics Achievement”. Sociology of Education, 60(2); 63-72.

[7] Harb Nasri, El-Shaarwi Ahmed (July 2006). 'Factors Affecting Students' Performance'. MPRAPaper No. 1362.

[8] Henderson A., Mapp K. (2002). A new wave of evidence: The impact of school, parent and community connections on student achievement. Austin, TX.: Southwest

Educational Development Laboratory, retrieved from website:

http://www.capmembers.com/cadet_programs/library/school_program_lesson_plans/doc uments/CAP5S-20.PDF.

[9] Mahathir M. (1991). The way forward. Paper presented to the Malaysian Business Council. Retrieved from: http://vlib.unitarklj1.edu.my/htm/w2020.htm

[10] MoE (2002). Educational Organization and, Community Participation and Financial Guideline: Addis Abeba EMPDA, August.

[11] MoE (2004). Continuous Professional Development. For school teachers. (A guideline). Addis Ababa, June. 
[12] Natriello Gary, Edward L. McDill (1986). "Performance Standards, Student Effort on Homework and Academic Achievement." Sociology of Education, (59)1; 18-31.

[13] Norhidayah Ali Kamaruzaman, Jusoff Syukriah Ali Najah, Salamt Mokhtar Azni Syafena Andin (20 December 2009). 'The Factors Influencing Students' Performance at Universiti Teknologi MARA Kedah, Malaysia'. Canadian Research \& Development Center of Sciences and Cultures, 3(4).

[14] OEB (2012). Education Statistics Annual Abstract. Finfinne Oromia: Oromia Education Bureau, May.

[15] OREB (2007). Maanwallil Acleemasa Hoji Kenna Degarsa Ogummaa fi Hordoffii Barnootaa. Garee JBAH BBO; Finfinee.

[16] Ornstain A. C., Hunkins (1998). Curriculum: Foundations, Principles and Issues, New Jersy: Prentice Hall.

[17] Raychaudhuri A., Debnath M., Sen S., Majumder B. (2010). Factors Affecting Students'Academic Performance: A case Study in Agartala Municial Councle Area. Bangladidh: E-journal of Sociology, 2.

[18] Rein Hartz J., Beach M. D. (1997). Teaching and Learning in the Elementary school: Focus on curriculum. New Jersey: Prentice Hall.

[19] Roberts Kerry L., Sampson Paulinen M. (2011). School board member professional development and effect on student achievement. International Journal of Educational Management, 25(7); 701-713.

[20] SMASEE (2012). Introducing Strengthening Mathematics and Science Education in Ethiopia (SMASEE) and monitoring and evaluation. Fabruary. Addis Ababa.

[21] Staver John R. (2007.) Teaching Science. France: Imprimerie Nouvelle Gonnet, 01300 Belley,

[22] TGE (1994). Transitional Government of Ethiopia, Education and Training Policy, Addis Ababa.

[23] Villegas-Reimers E. (2003). Teacher Professional Development: an International Review of the Literature UNESCO: International Institute for Educational Planning, IIEP's Print Shop.

[24] Wittrock C. M. (1994). Generative Science Teaching. In Peter, J. F., Richard, F. G. \& Richard, T. W. (Ed), the content of science: a constructivist approach to its teaching and learning. Hongkong: Graphicraft Type Setters Ltd.

[25] Zewdu Gebrekidan (2010). Ethiopian National Assessment of Grade 10 and 12 students. National Agency for Examination. December, 2010, Addis Ababa, Ethiopia.

[26] Abdulrahaman W. Lawal, International Letters of Social and Humanistic Sciences 3 (2014) 53-59.

[27] Akor Isaiah Akem, Victor Tavershima Ukeli, International Letters of Social and Humanistic Sciences 4 (2014) 49-59.

[28] Peace Ebele Ilechukwu Chukwbikem, International Letters of Social and Humanistic Sciences 8(1) (2014) 1-17. 
[29] Halima Sidi Bamall, International Letters of Social and Humanistic Sciences 8(1) (2014) 50-55.

[30] Dennis Agama Eka, International Letters of Social and Humanistic Sciences 8(2) (2014) 170-182.

[31] Hannatu Abdullahi, International Letters of Social and Humanistic Sciences 8(3) (2014) 217-223.

[32] Fowoyo Joseph Taiwo, International Letters of Social and Humanistic Sciences 8(3) (2014) 244-251. 